\title{
Slow-Twitch Myofibers are Observed in Masseter Muscle of the Hypothalamic Obese Rat
}

\author{
Noboru MANABE, Takehiko Ishibashi and Hajime MiYamoto \\ Department of Animal Science, Faculty of Agriculture, \\ Kyoto University, Sakyo-ku, Kyoto-shi 606-01
}

(Received November 9, 1992)

\begin{abstract}
The composition of the myofiber types classified immuno- and enzymehistochemically were investigated in 12 muscles (M. masseter, M. trapezius, M. triceps brachii, M. extensor carpi radialis, M. pectoralis profundus, M. longissimus, M. Biceps femoris, M. semitendinosus, M. semimembranosus, $M$. extensor digitorum longus, $M$. soleus and $M$. gastrocnemius) of the obese rats with hypothalamic lesions operated at 25-28 day-old. The cross sectional area of each myofiber type was measured using automatic image analyzer. At 90 days after the operation, in the sham operated control animals (10 male rats), the masseter muscle was uniformly composed of fast-twitch type myofibers (Type IIA and IIB), which reacted for anti-fast-myosin monoclonal antibody and for alkali-stable myosin adenosine triphosphatase (ATPase) and were unreactive for acid-stable myosin ATPase. In the operated obese animals (10 male rats), however, the masseter muscle had not only fast-twitch myofibers but also slow-twitch myofibers (Type I), which reacted strongly for acid-stable myosin ATPase and were not reactive for anti-fast-myosin monoclonal antibody or for alkali-stable myosin ATPase, and showed a hypertrophy of myofibers. In comparison with sham-control rats, no change of histochemical fiber type composition was observed in other 11 muscles. All fiber types of these 11 muscles of the obese group were smaller in cross-sectional area than those of the sham-control group myofibers. It is suggested that the difference of the fiber type composition between the obese rats and the control rats indicates the transformation of the myofiber types from the fast-twitch type into slow-twitch type. It is considered that an adaptation to long-term jaw movements in the masseter muscle of the obese rats may lead to changes in composition of myofiber types.
\end{abstract}

Anim. Sci. Technol. (Jpn.) 64 (5) : 440-447, 1993

Key words: myofiber type, hypothalamic obese rat, histochemistry, morphometry

In mammals the hypothalamus contains very important sites controlling food intake. The bilateral lesions in the region of the ventromedial nuclei cause hyperphagia and bring about extreme obesity in the rat $^{6,7)}$. Such hypothalamic obese rats are noticed by many investigators in various research fields, because these can be easily produced by surgical and electrolytical means with an aid of stereotaxic instrument and change physiologically, endocrinologically, pharmacologically, morpho- logically and ecologically $2,3,8,9,22,30)$. However, no studies on the histochemical characteristics of myofiber in the obese rats with hypothalamic lesions have been reported yet. The aim of the present study, therefore, is to demonstrate the histochemical properties of the myofibers in 12 muscles of the obese rats.

\section{Materials and Methods}

Twenty male Wistar rats, 25-28 days of age, were used. The animals were maintained in a 
room at $23 \pm 2^{\circ} \mathrm{C}$ in which the light cycle was artificially controlled (12 h light, $12 \mathrm{~h}$ dark), and were provided food (rat chow) and water ad libitum. They were divided randomly into 2 groups. Ten rats (obese group) received electrolytic lesions in the ventromedial region of the hypothalamus under an anesthesia with sodium pentobarbital ( $5 \mathrm{mg} / \mathrm{kg}$. i.p), and the remaining 10 rats (sham-control group) received sham-operation. The method of the operation was described in previous papers ${ }^{8,9}$.

At 90 days after the operation, the animals were sacrificed by decapitation under ether anesthesia. Twelve muscles ( $M$. masseter, M. trapezius, M. triceps brachii (Caput laterale), M. extensor carpi radialis, M. pectoralis profundus, $M$. longissimus thoracis, M. Biceps femoris (Caput longum), M. semitendinosus, M. semimembranosus, $M$. extensor digitorum longus, M. soleus and M. gastrocnemius (Caput laterale)) were carefully removed. The muscle samples (4-5 $\mathrm{mm}$ thick) sliced transversely in the midbelly region were mounted on a filter paper, and then were frozen in a mixture of dry ice and isopentane. Serial transverse sections $(6 \mu \mathrm{m})$ were cut on a cryostat. Unfixed sections were incubated for histoenzymatical demonstration of myosin ATPase, succinate dehydrogenase (SDH), nicotinamide adenine dinucleotide tetrazolium reductase (NADH-TR) and $\alpha$-glycogen phosphorylase (PhR) activities as previously reported ${ }^{16-191}$. The frozen sections were also stained immuno-histochemically using monoclonal anti-fast myosim antibody (MY-32 clone. Sigma Chem. Co., St. Louis, USA), which was produced using rabbit fast-myosin (type II myosin) as immunogen. The immunohistochemical method employed in this study were as follows. The frozen sections were fixed in acetone cooled at $-80^{\circ} \mathrm{C}$ for $5 \mathrm{~min}$ and then were placed in $100 \%$ methanol with $0.3 \%$ hydrogen peroxide for $5 \mathrm{~min}$ at room temperature to block endogenous peroxidase activity. They were treated with $0.1 \%$ normal goat serum for $30 \mathrm{~min}$ at room temperature.
The primary monoclonal antibody, which was diluted in $0.1 \%$ bovine serum albumin, $0.01 \mathrm{M}$ phosphate buffered saline (PBS, pH 7.4) to produce a $1 / 400$ solution, was incubated with the sections for $18 \mathrm{hr}$ at $4^{\circ} \mathrm{C}$. After washing in PBS, the sections were incubated with biotinylated goat anti-mouse immunoglobulin and peroxidase-conjugated streptavidin from Vector Laboratories (Burlingame, USA) for 60 min at room temperature. The sections were again washed with three changes of PBS. The antigen-antibody complex was subsequently visualized by immersion in substrate solution $10.05 \% 3-3$-diaminobenzidine tetrachloride, $0.01 \% \mathrm{H}_{2} \mathrm{O}_{2}, 0.05 \mathrm{M}$ Tris- $\mathrm{HCl}, \mathrm{pH} 7.2$ ) for 5 min at room temperature. Control sections were incubated with normal mouse serum. Myofibers were classified into types 1, IIA and IIB by differences in reactivity for these enzymes and antibody.

The photomicrographs were taken of cross sections stained with anti-fast myosin antibody and NADR-TR to determine the percentage of myofiber types and to measure the cross-sectional area. A total of 500-600 fibers per muscle section were classified and examined. Cross-sectional areas of 100-150 fibers in each myofiber type per muscle section were measured using automatic image analyzer system (BIOCOM-2000, Biocom, Paris, France).

Paired Student's t test was used to evaluate the significance of any differences in means between the groups. Differences between means were considered significant at $P<0.05$. Each value represented mean $\pm S$.D. .

\section{Results}

As shown in Table 1, myofibers were categorized into types I (slow-twitch-oxidative), IIA (fast-twitch-oxidative-glycolytic) and IIB (fast-twitch glycolytic). In type I fibers negative reaction against anti-fast myosin antibody and high acitivities of acid-stable myosin ATPase, SDH and NADH-TR were observed. In type IIA fibers positive reaction against 
Table 1. Histochemical characteristics of myofiber types in male rat muscles

\begin{tabular}{|c|c|c|c|c|c|c|}
\hline $\begin{array}{c}\text { Myofiber } \\
\text { type }\end{array}$ & $\begin{array}{l}\text { Anti-fast } \\
\text { myosin } \\
\text { antibody }\end{array}$ & $\begin{array}{c}\text { Acid-stable } \\
\text { myosin } \\
\text { ATPase }^{1}\end{array}$ & $\begin{array}{c}\text { Alkali-stable } \\
\text { myosin } \\
\text { ATPase }^{2}\end{array}$ & $\mathrm{SDH}$ & NADH-TR & $\mathrm{PhR}$ \\
\hline I & Negative & $\mathrm{HH}^{3}$ & - & m & HI & $-1+$ \\
\hline II $\mathrm{A}$ & Positive & - & $H$ & H/H & $\mathrm{H} / \mathrm{HWH}$ & H \\
\hline II B & Positive & - & $H$ & + & + & $H / H H$ \\
\hline
\end{tabular}

1 Preincubation at $\mathrm{pH} 4.3$.

${ }^{2}$ Preincubation at $\mathrm{pH} 10.5$.

${ }^{3}$ Enzyme activities: -, Unreactive; + , weak; H, strong; H, very strong.

anti-fast myosin antibody and high activities of alkali-stable myosin ATPase, SDH and NADH-TR were observed. In type IIB fibers positive reaction against anti-fast myosin antibody and high activities of alkali-stable myosin ATPase, and PhR were observed.

There was a significant difference in the obesity index ${ }^{21}$ between the obese group $(0.412$ $\pm 0.009)$ and the sham-control group $(0.311 \pm$ $0.003)(\mathrm{P}<0.01)$.

Composition of myofiber types was shown in Table 2. In sham-control group, the masseter muscle has types IIA and IIB fibers (61.4 \pm 3.9 and $38.6 \pm 3.9 \%$, respectively), but no type $I$ fiber was present (Fig. 1). In obese group, however, the masseter muscle contained types I, IIA and IIB $(8.2 \pm 1.6,66.6 \pm 3.7$ and $25.2 \pm 3.8$ $\%$, respectively (Fig. 2). These slow-twitch (type 1) myofibers were dominantly found in the deepest part of the masseter muscle. In other 11 muscles studied, there was no significant difference in myofiber type composition between the two groups.

Cross-sectional area of myofiber types was also given in Table 2. In the masseter muscle, types IIA and IIB fibers of obese rats (2568 160 and $3231 \pm 174 \mu^{2}$, respectively) were significantly $(\mathrm{P}<0.05)$ larger in cross-sectional area than type IIA and IIB fibers of shamcontrol rats $\left(2347 \pm 186\right.$ and $2828 \pm 162 \mathrm{\mu m}^{2}$, respectively). In obese group, the cross-sectional area of type I fibers $\left(2354 \pm 236 \mu \mathrm{m}^{2}\right)$ was smaller than that of types IIA and IIB fibers. However, all myofiber types in other
11 muscles of the obese rats were smaller in cross-sectional area than those of the shamoperated rats.

\section{Discussion}

It was clear from the obesity indexes of obese and sham-control groups that the operation of the electrolytic lesione in the ventromedial region of hypothalamus was successful in the present study ${ }^{2}$.

The percentages and cross-sectional areas of histochemical myofiber types in the 12 muscles of sham-control group were similar to those reported previously $1,14,21,25-28,31$. Except for the masseter muscle, the myofiber type populations in the remaining 11 muscles of the obese rats also similar to those of the previous articles $^{1,14,21,25-28,31)}$. Previous reports ${ }^{27,28)}$ demonstrated that the masseter muscle was uniformly composed of fast-twitch (type IIA and IIB) myofibers. However, the masseter muscle in the obese rats contained not only fast-twitch myofibers (type IIA and IIB fibers) but also slow-twitch myofibers (type I fibers). With the exception of the masseter muscle, the cross-sectional areas in the remaining 11 muscles of the obese rats were smaller than those of sham-operated rats. The cross-sectional area in the masseter muscle of the obese group was significantly larger than that of the shamcontrol group. That is to say, the fiber type composition and myofiber size of the rat masseter muscle changed after the operation of the electrolytic hypothalamus lesions. 
Table 2. Comparison of the percentage and cross sectional area of myofiber types in twelve muscles between the obese and sham-control rats

\begin{tabular}{|c|c|c|c|c|c|}
\hline Muscle & Fiber type & \multicolumn{2}{|c|}{ Percentage $(\mathscr{\%})$} & \multicolumn{2}{|c|}{$\operatorname{Area}^{1}\left(\mu \mathrm{m}^{2}\right)$} \\
\hline \multirow[t]{3}{*}{ Masseter } & I & - & $8.2 \pm 1.6$ & - & $2354 \pm 236$ \\
\hline & IIA & $61.4 \pm 3.9$ & $66.6 \pm 3.7$ & $2347 \pm 186$ & $2568 \pm 160$ \\
\hline & IIB & $38.6 \pm 3.9$ & $25.2 \pm 3.8$ & $2828 \pm 162$ & $3213 \pm 174$ \\
\hline \multirow[t]{3}{*}{ Trapezius } & $\mathrm{I}$ & $3.6 \pm 0.8$ & $3.8 \pm 1.3$ & $2161 \pm 267$ & $2106 \pm 202$ \\
\hline & IIA & $61.4 \pm 3.9$ & $66.6 \pm 3.7$ & $2899 \pm 323$ & $2743 \pm 246$ \\
\hline & IIB & $35.0 \pm 4.2$ & $29.6 \pm 3.0$ & $3929 \pm 156$ & $3739 \pm 117$ \\
\hline \multirow[t]{3}{*}{ Triceps brachii } & I & $4.0 \pm 1.3$ & $4.2 \pm 1.5$ & $1817 \pm 132$ & $1626 \pm 151$ \\
\hline & IIA & $33.4 \pm 3.1$ & $32.8 \pm 3.3$ & $2058 \pm 359$ & $1937 \pm 201$ \\
\hline & IIB & $62.6 \pm 2.9$ & $63.0 \pm 4.0$ & $4104 \pm 299$ & $3973 \pm 263$ \\
\hline \multirow{3}{*}{$\begin{array}{l}\text { Extensor carpi } \\
\text { radialis }\end{array}$} & I & $5.4 \pm 0.8$ & $5.2 \pm 1.8$ & $1196 \pm 270$ & $1107 \pm 115$ \\
\hline & IIA & $45.2 \pm 2.5$ & $45.6 \pm 2.9$ & $1673 \pm 173$ & $1540 \pm 160$ \\
\hline & IIB & $49.4 \pm 3.0$ & $49.2 \pm 4.1$ & $4756 \pm 212$ & $4566 \pm 211$ \\
\hline \multirow{3}{*}{$\begin{array}{l}\text { Pectralis } \\
\text { profundus }\end{array}$} & I & $8.6 \pm 2.2$ & $8.4 \pm 1.8$ & $2433 \pm 142$ & $2208 \pm 192$ \\
\hline & IIA & $67.8 \pm 3.6$ & $69.2 \pm 4.1$ & $3099 \pm 162$ & $2783 \pm 166$ \\
\hline & IIB & $23.6 \pm 5.8$ & $22.4 \pm 4.0$ & $3892 \pm 182$ & $3799 \pm 196$ \\
\hline \multirow{3}{*}{$\begin{array}{c}\text { Longissimus } \\
\text { thoracis }\end{array}$} & 1 & $8.8 \pm 2.5$ & $8.6 \pm 2.7$ & $1929 \pm 260$ & $1893 \pm 232$ \\
\hline & IIA & $58.4 \pm 2.9$ & $56.8 \pm 3.3$ & $2814 \pm 203$ & $2631 \pm 344$ \\
\hline & IIB & $32.8 \pm 4.4$ & $34.6 \pm 4.1$ & $3991 \pm 249$ & $3838 \pm 276$ \\
\hline \multirow[t]{3}{*}{ Biceps femoris } & I & $2.6 \pm 1.3$ & $3.0 \pm 1.0$ & $1922 \pm 209$ & $1766 \pm 260$ \\
\hline & II A & $29.8 \pm 2.9$ & $30.4 \pm 2.9$ & $2294 \pm 478$ & $2123 \pm 201$ \\
\hline & IIB & $67.6 \pm 2.8$ & $66.6 \pm 2.9$ & $4227 \pm 291$ & $4071 \pm 410$ \\
\hline \multirow[t]{3}{*}{ Semitendinosus } & I & $7.8 \pm 0.6$ & $8.4 \pm 0.9$ & $1689 \pm 298$ & $1613 \pm 211$ \\
\hline & IIA & $47.6 \pm 2.7$ & $47.2 \pm 1.9$ & $1960 \pm 203$ & $1904 \pm 262$ \\
\hline & IIB & $44.6 \pm 2.8$ & $44.4 \pm 2.1$ & $4848 \pm 328$ & $4761 \pm 267$ \\
\hline \multirow[t]{3}{*}{ Semimembranosus } & I & $5.6 \pm 1.3$ & $5.2 \pm 1.6$ & $2556 \pm 613$ & $2435 \pm 383$ \\
\hline & II A & $36.8 \pm 2.6$ & $37.2 \pm 1.9$ & $3760 \pm 451$ & $3562 \pm 363$ \\
\hline & IIB & $58.0 \pm 2.8$ & $57.6 \pm 2.4$ & $6093 \pm 412$ & $5960 \pm 296$ \\
\hline \multirow{3}{*}{$\begin{array}{l}\text { Extensor digitorum } \\
\text { longus }\end{array}$} & I & $5.0 \pm 1.9$ & $4.6 \pm 1.1$ & $1231 \pm 327$ & $1159 \pm 147$ \\
\hline & IIA & $45.6 \pm 2.2$ & $44.4 \pm 2.4$ & $1743 \pm 132$ & $1604 \pm 109$ \\
\hline & IIB & $49.4 \pm 3.6$ & $51.0 \pm 2.7$ & $4943 \pm 456$ & $4714 \pm 378$ \\
\hline \multirow[t]{3}{*}{ Soleus } & $I$ & $85.0 \pm 1.7$ & $85.8 \pm 1.9$ & $4023 \pm 201$ & $3871 \pm 218$ \\
\hline & IIA & $15.0 \pm 1.7$ & $14.2 \pm 1.9$ & $3781 \pm 264$ & $3636 \pm 237$ \\
\hline & IIB & - & - & - & - \\
\hline \multirow[t]{3}{*}{ Gastrocnemius } & I & $8.4 \pm 1.3$ & $9.0 \pm 1.6$ & $2401 \pm 353$ & $2299 \pm 222$ \\
\hline & IIA & $28.0 \pm 2.2$ & $28.4 \pm 1.8$ & $2443 \pm 466$ & $2141 \pm 191$ \\
\hline & IIB & $63.6 \pm 2.7$ & $62.6 \pm 2.6$ & $4236 \pm 441$ & $4105 \pm 221$ \\
\hline
\end{tabular}

Each value represents mean \pm S.D. ${ }^{1}$ Cross sectional area of myofibers.

It was reported that the change of slowtwitch myofibers into fast-twitch myofibers occurred as a result of brief strengthening exercise in the rat soleus muscle, whereas the change of fast-twitch myofibers into slow- twitch myofibers occurred as a result of low intensive-prolonged duration exercise in the soleus muscle ${ }^{9}$. The percentages of myofiber types also changed after endurance training in rat hind limb muscles ${ }^{21)}$. Recently, histo- 


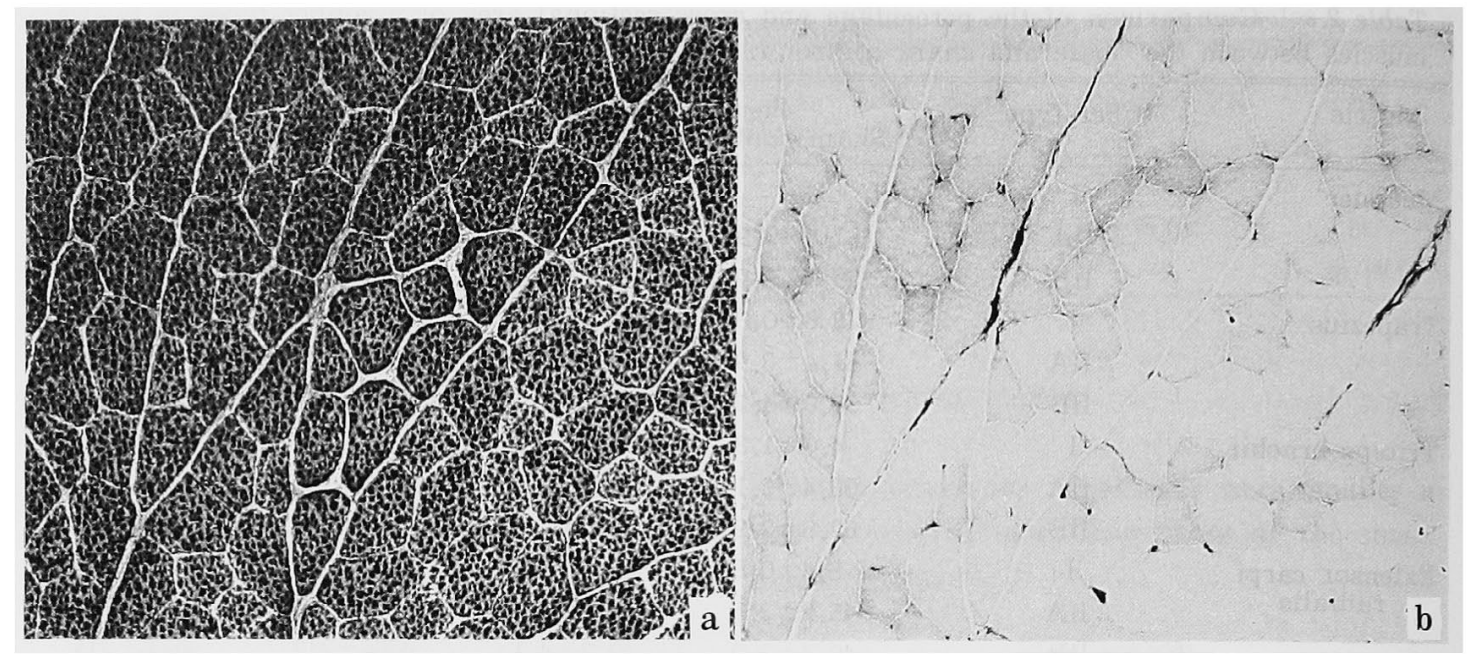

Fig. 1. Light micrographs of the masseter muscle of adult male Wistar rats with sham operation. Serial sections $(6 \mu \mathrm{m}$ thick) of the muscle are stained for antifast-myosin monoclonal antibody (a) and for acid-stable myosin ATPase preincubated at $\mathrm{pH} 4.3$ (b). Only fast-twitch myofibers are demonstrated. No slow-twitch myofiber is present. $\times 120$

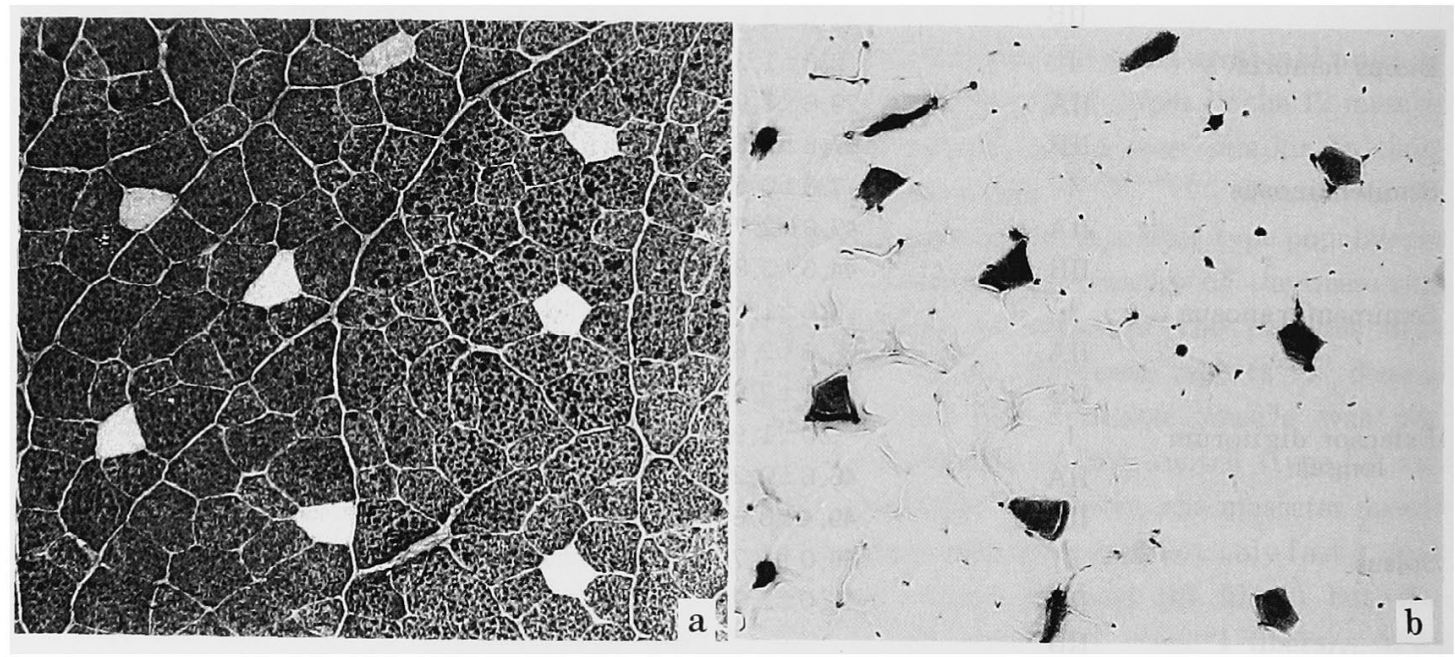

Fig. 2. Light micrographs of the masseter muscle of adult male Wistar rats with hypothalamic lesions. The muscle tissue sections are stained for anti-fast-myosin monoclonal antibody (a) and for acid-stable myosin ATPase preincubated at pH 4.3 (b). The masseter muscle contained both slow-twitch and fast-twitch myofibers. x 120

chemical fiber composition changed in rat soleus and gastrocnemius muscles after hypoand hyperthyroidism treatment ${ }^{15)}$. In Japanese quail anterior latissimus dorsi muscle, which is unique amongst vertebrates since it has been considered to be made up by true slow fibers, fast myosin positive myofibers with hypertrophy were demonstrated immunohistochemically after prolonged strethch ${ }^{20)}$. This finding revealed the myofiber type transformation 
Myofiber Characteristics in the Obese Rat

from the slow-twitch type into fast-twitch type in avian skeletal muscle. Our result demonstrates the transformation of the histochemical myofiber types from the fast-twitch type into slow-twitch type in mammalian skeletal muscle. Many factors, i.e. stretch $^{203}$, exercise $^{4,12.21}$, surgical and functional over$\operatorname{load}^{11,29)}$, denervation ${ }^{13,23)}$, reinnervation ${ }^{5,13)}$, neuron secreting substances ${ }^{243}$, thyroid and sex hormones ${ }^{5,15)}$, etc., contribute the transformation of the muscle fiber types. However, the molecular mechanism of the myosin isoform transition is undefined.

Endocrinological and ecological properties of the hypothalamic obese rats were different from those of the control rats ${ }^{2,3,6-10,22,30)}$. If endocrinological change in the obese rats played a causative role in the transformation of myofiber type, the fiber composition in most of the muscle studied should change as in case of hypo- and hyperthyroidism rats ${ }^{15)}$. Food intake time was increased about threefold in rats with hypothalamic lesions ${ }^{7,8,10\}}$, so it was considered that duration of jaw movement in eating was longer in the obese rats than in the control rats. This prolonged jaw movement in the obese rats may lead to the changes of immunohistochemical and histoenzymatical characteristics of the masseter myofibers. It is suggested that the difference of the fiber type composition between the obese rats and the control rats indicates the transformation of myofiber types.

\section{Acknowledgement}

The authors wish to express our deep gratitude to Drs. E. Sato, J-A. Grimaud and C. PORTo for their valuable suggestions regarding the hypothalamic obese operation and morphometrical analysis, and also thank Mr. K. Matsumoto for his skillful operation assistance.

\section{References}

1) Armstrong, R.B. and R.O. Phelps, Muscle fiber type composition of the rat hindlimb. Am. J. Anat., 171 : 256-272. 1984.

2) Bernardis, L.L.. and F.R. Skeleton, Growth and obesity in male rats after placement of ventromedial hypothalamic lesions at four different ages. J. Endocrine., $38:$ 351-366. 1967.

3) BRовеск, J.R., Mechanism of the development of obesity in animals with hypothalamic lesions. Fhysiol. Rev., 26 : 541559. 1946.

4) Golospink, G, and P.S. WARD, Changes in rodent muscle fiber types during postnatal growth, undernutrition and exercise. J. Physiol., 296 : 453-469. 1979.

5) Hanzlikova, V. and E. Gutmann, Effect of foreign innervation of the androgen-sensitive levator ani muscle of the rat. Z. Zellforsch., 135: 165-174. 1972.

6) Hetherington, A.W. and S.W. Ranson, Hypothalamic lesion and adiposity in the rat. Anat. Rec., 78 : 149-171. 1940.

7) Hetherington, A.W. and S.W. Ranson, The spontaneous activity and food intake of rats with hypothalamic lesion. Am. J. Physiol., 136 : 609-617. 1942.

8) Ishibashi, T., Y. Shimoda, H. MiYamoto and E. Sato, Physiological studies on the obese rats with hypothalamic lesions. Mem. Coll. Agric. Kyoto Univ., 109: 5561. 1977.

9) Ishibashi, T, and H. Miyamuto, E. Sato, and T. IsHII, Histological observations on the anterior pituitary of the obese rats with hypothalamic lesions. Mem. Coll. Agric. Kyoto Univ., 119: 35-51. 1982.

10) Kennedy, G.C., Food intake, energy balance and growth. Brit. Med. Bull., 22: 216-220. 1966.

11) JAMES, N.T., Studies on the response of different types of muscle fibre during surgically induced compensatory hypertrophy. J. Anat., 129: 769-776. 1979.

12) JAWEed, M.M., G.J. HARBison and J.F. Ditunno, Myosin ATPase activity after strengthening exercise. J. Anat,, 124: 371381. 1978.

13) JAWEED, M.M., G.J. HARBISON and J.F. Ditunno, Denervation and reinnervation of fast and slow muscles. J. Histochem. Cytochem., $23:$ 808-827. 1975.

14) Khan, M.A., Histoenzymatic characterization of subtypes of type 1 fibers in fast 
muscles of rats. Histochemistry, 55: 129 138. 1978.

15) Lomax, R.B. and W.R. Robertson, The effects of hypo- and hyperthyroidism on fibre composition and mitochondrial enzyme activities in rat skeletal muscle. $\mathrm{J}$. Endocrinol., $133:$ 375-380. 1992.

16) Manabe, N., E., Sato S. Watanabe, and T. IsHiBAsH, The skeletal muscle fiber types of the mammals. I. Nyctereus procynoides, Mustela itatsi,. Canis familiaris, Rhinolophus ferrumequinum, Crocidula dsinezumi. J. Mammal. Sci., 40: 89-94. 1980.

17) Manabe, N., E. Sato and T. Ishibashi, Histochemical analysis of sheletal muscle fibers in the copper pheasant (Phasianus soemmerringii). Tori, 29: 109-120. 1981. (Japanese)

18) Manabe, N., T. Ishil and T. Ishibashi, $p H$ stability of myosin adenosine triphosphatase activity of the muscle fibers in the growing cattle, sheep and swine. Jpn. J. Zootech. Sci., 53 : 64-66. 1982. (Japanese)

19) Manabe, N., T. Ishil and T. Ishlbashl, Histochemical fiber type composition and fiber size in sheletal muscles of the growing cattle, sheep and swine. Mem. Coll. Agric. Kyoto Univ., 131 : 27-36. 1988.

20) Matrhews, W., R.R. Jenkins and W.J. GonyeA, Myosin isozyme expression in response to stretch-induced hypertrophy in the Japanese quail. Anat. Rec., 228: 255261. 1990.

21) Multer, W., Temporal progress of muscle adaptation endurance training in hind limb muscles of young rats. A. Histo. chemical and morphometrical study. Cell Tiss. Res., 156 : 61-87. 1974.

22) Nishizawa, Y., Y. Okui, M. Inaba, $S$. Okuno, K. Yukioka, T. Miki, Y. Watanabe and H. MORI, Calcium/calmodulinmediated action of calcitonin on lipid metabolism in rats. J. Clin. Invest., 82 ;
$1165^{-1172,1988 .}$

23) Ono, Y., T. Goto and S. Nishimura, The effect of denervation on the degenerative process of type I fibers in the biceps brachii muscle of the chick. Anim. Sci. Technol, (Jpn), 63: 805-808. 1992.

24) $\mathrm{OH}$, T.H. and G.J. Markelonis, Neuro trophic effects of a protein fraction isolated from peripheral nerve on skeletal muscle in culture. in Muscle Regeneration. (Mauro A. eds.) 419-428. Raven Press. New York. 1980.

25) Pullen, A.H., The distribution and relative sizes of three histochemical fibre types in the rat tibialis anterior muscle., J.Anat., 123 : 1-19. 1977.

26) Pullen, A.H., The distribution and relative sizes of fibre types in the extensor digitorum longus and soleus muscles of the adult rat., J.Anat., 123:467-486. 1977.

27) Schiffino, S., Histochemical enzyme profile of the masseter muscle in different mammalian species. Ant. Rec., 180: 53-62. 1974.

28) Suzuki, A., A comparative histochemical study of the masseter muscle of the cattle, sheep, swine, dog, guinea pig and rat. Histochemistry, 51: 121-131. 1977.

29) TomaneK, R.J., A histochemical study of postnatal differentiation of skeletal muscle with reference to functional overload. Dev. Biol., 42 : 305-314. 1975.

30) Usami, M., Y. Seino, S. Nishi, H. Nakahara, M. Ikeda, S. Matsukura and H. IMUrA, Effect of mazindol on insulin and glucagon secretion in ventromedial hypothalamic obese rats. Nippon Yakurigaku Zasshi, 85 : 297-303, 1985. (Japanese)

31) YelLIN, H., Difference in histochemical attribution between diaphragm and kindley muscles of the rat. Anat. Rec., 173: 333340. 1972. 


\title{
視床下部性肥満ラットの咬筋に遅筋線維が観察される
}

\author{
眞鍋 昇- 石橋武彦・宮本 元
}

京都大学農学部, 京都市左京区 606-01

\begin{abstract}
各10匹のラットに視床下部満腹山枢破壊手術および擬手術を25２8日龄で施した。手術後 90 日の

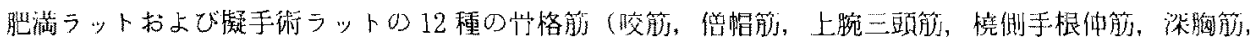

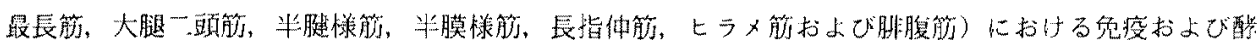

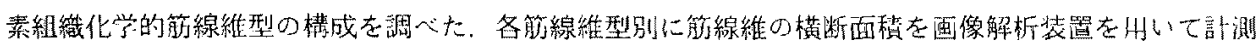

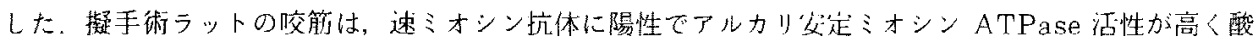
文定ミオシンATPase 洁性の低い速筋線維（II A および II B 型）のみから满成されていた。しかし， 視床下部性肥満ラットの咬筋においては, これらの速筋線維以外に, 速ミオシン抗体に陰性でアルカり 安定ミオシンATPase 活性が低く酸交定ミオシンATPase 活性の高い遅筋線維（I型）が観察され，

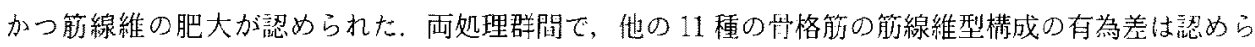
机なかったが，視床下部性肥満ラットの笳線維の横断面䆄は全ての符線維型で擬手術ラットより小さか った，以上の結果から，速筋線維から遮筋線維一筋線維型が変换するこ上が判明した，この变換は，視

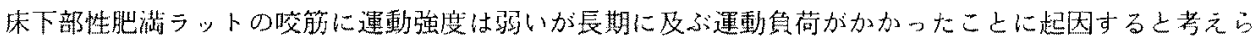
れた。
\end{abstract}

日畜会報，64(5)：440-447, 1993 